\title{
Tax Stabilization Clause in Oil and Gas Industry
}

\author{
Wishnoe Saleh Thaib \\ Department of Law \\ University of Borobudur \\ Jakarta, Indonesia \\ borobudur.wishnoe@gmail.com
}

\author{
Faisal Santiago \\ Department of Law \\ University of Borobudur \\ Jakarta, Indonesia \\ faisalsantiago@borobudur.ac.id
}

\begin{abstract}
An investor in oil and gas industry take the risk of concluding a long-term contract with a state counterparty that has the power at any time to change the tax law applicable to its contract. In this situation a state party cannot reassure an investor counterparty sufficiently to take such a risk.

Tax risk is something that can be managed and thereby minimized - for the good of both the state hosting the resource and the extractive company. A number of tools exist to manage this risk; this paper looks at the tax stabilization clause as it is a particularly popular option for investors.
\end{abstract}

This paper takes a qualitative approach through an investigation into literary works and explores how and why the tax stabilization clause has become a popular option for tax risk management. These clauses have been heavily criticized by various stakeholders and yet they remain as relevant today as when they were first shaped in the 20th century. This paper also looks at the controversy surrounding the validity of such clauses by examining various doctrinal writings and international arbitration rulings. The investigation reveals a shift in the tax stabilization clause's scope, and more importantly its objective, over the years. Drafters as well as legal opinion seems to be at odds with the restrictive nature of yesteryear clauses, which may unjustly tie the hands of a host state — and as such a more balanced approach is sought.

These considerations lead to the main thrust of the study which is to determine what practical drafting steps can be taken to ensure the efficacy of these clauses. The focus leans on the most pertinent substantive components that such a clause should contain to ensure the risks and benefits of resource development are shared fairly. The procedure and objective of the renegotiation mechanism contained the clause is particularly important as it is this key ingredient that makes or breaks the tax stability of a project. The study builds on extensive writings on the subject and attempts to build a body of best practice in this regard.

Keywords - tax stabilization clause, oil and gas agreement

\section{INTRODUCTION}

Most oil and gas contracts are long-term agreements that cover long time periods. It comes as no surprise that a lot may change with time, especially in developing countries. Governments may change their policy which might have a significant impact on the government and investor, or even directly interfere with the long-term agreements such as expropriation, the obsolescence bargain, and changes in circumstance. As a result, there is a need to offer government and investors some protection from future unforeseen circumstances and significant changes. Stabilization, hardship, force majeure and price review clauses are often resorted to for such protection.

In response to the possibility of modification of contractual rights by unilateral governmental actions, a significant number of contracts include stabilization clauses. The function of these clauses is to ensure that the contract will not be altered and will remain "stabilized". Basically, stabilization clauses serve as a risk mitigation tool for investors. The sole objective of the stabilization clause is "to preclude the application to an agreement of any subsequent legislative (statutory) or administrative (regulatory) act issued by the government or the administration that modifies the legal situation of the investor." [1]

The Tax Stabilization Clause, which is the primary focus of this study, is a mechanism which is used to deal with the risk of changing tax laws that may have an adverse effect on the financial viability of a project. A tax stabilization clause is aimed at rendering an agreement and the underlying project's taxterms immune from any subsequent adverse act of the government,whether legislative or administrative.[2] Thus "ensuring that the law of the host state, in so far as it impacts on the economic and financial performance of an investment venture, remains unchanged for the duration of the investment venture or such other period as may be agreed between the host state and the investor. However, its raises major questions like, 'Do tax stabilization clause restrict the state from enacting legislations?' 'Do they render the terms of the contract unchallengeable?'. This paper seeks to elucidate best practice principles of contractual drafting, especially in tax stabilization clause.

\section{LITERATURE REVIEW}

Faruque (2005) in his research revealed two essential issues that form part of the rationale for stability of oil and gas contracts have been raised in scholarly literature. The first is that the long term nature of oil and gas contracts brings the unavoidable risk that changes of circumstances mayeventually materialize and may frustrate the objectives of the parties.[2] Therefore if the contractual relationship seeks to survive these changes it must find stability by anticipating and dealing with the reaction to such changes. Secondly, because oil and gas contracts involve the state as a party in most cases (a state owned entity in others), the issue of state sovereignty must be dealt with.

A second study by Maniruzzaman (2005) revealed that Stabilization clauses come in different categories in terms of nature and scope. There are three main types of stabilization clauses: the freezing clauses, economicbalancing clauses and 
hybrid clauses. The freezing clause, also known as thetraditional approach, is designed to make new laws inapplicable to the oil and gas contract. The economic balancing clause, also known as the modern approach, provides that although new laws will apply to the investment, the investor will be compensated for the cost of complying with them. The hybrid clause is a combination of freezing and balancing clauses. ${ }^{1}$ The scope of such clauses can be sweeping covering every law/regulation that affects the contract. Alternatively, it could cover only certain areas of the law such as fiscal, social or environmental laws.

Cameron PD (2006) in his research has analyzed the validity of the tax stabilization from a domestic law context and an international law context. From a domestic point of view, any undertakings given by the host state's government must be given in a form that is consistent with the state's legal and constitutional framework. From an international law point of view, he have held such clauses to be invalid under the 'state sovereignty argument', providing that states have permanent sovereignty over their natural resources which they cannot contract out of. A country will always retain the sovereign power to enact new laws that may supersede existing laws and contracts, however it is this very sovereignty of thestate that gives it the power to grant rights which it is prohibited from breaching. ${ }^{2}$ The prevalent view today is that a stabilization clause does not limit the state's sovereignty. Instead, a state's agreement to be bound by a stabilization clause is considered a valid exercise of that state's sovereignty.[3]

\section{METHODOLOGY}

This is a desk and library literature based research. It analyses both the relevant primary and secondary sources of information on the topic and reliance is placed on materials such as petroleum contracts, journals, textbooks, arbitral case law, conference papers, law reports, legislation and internet sources.

Because this study seeks to elucidate best practice principles of contractual drafting, the net has been cast quite widely with respect to the timeframe as well as jurisdictionby not prescribing any limit or scope for either. Thus, the study will consider the jurisprudence of quite a wide array of countries but limited to oil and gas agreements.

\section{RESUltS AND ANALYSIS}

An action by a host state, implementing new taxes and royalties, can decimate the profitability and attractiveness of a project. On the other hand, host states are looking for ways to become more attractive to investors and to stimulate investment into the development of their natural resources.

Thus, investors and host states are looking for stabilization mechanisms that have functional value and will ensure the costs and rents of exploration and exploitation are stable and predictable - at least from a taxes policy point of view.

\footnotetext{
See generally Shemberg, Cameron, Dansun, Maniruzzaman

Saudi Arabia v. Arabian American Oil Co the court held "[by\} reason of its wry sovereignty within its territorial domain, the state possesses the legal powers to grant rights [by] which it forbids itself to withdraw before the end of the concession."
}

A good way to manage this dynamic relationship and mitigate the risk of unilateral action by the state is to implement a tax stability clause, that deals exclusively with taxes and royalties, which will balance the interests of the parties and keep the investment attractive.

A tax stabilization clause is aimed at rendering an agreement and the underlying project's taxterms immune from any subsequent adverse act of the government, whether legislative or administrative.[2] Thus, ensuring that the law of the host state, in so far as it impacts on the economic and financial performance of an investment venture, remains unchanged for the duration of the investment venture or such other period as may be agreed between the host state and the investor.

Therefore, such clauses do not preclude a state from enacting new legislation, but rather prevent it from enforcing new tax regulations against the other contractual party, examples:

"The tax regime, benefits, privileges and exemptions provided in any of the articles hereof, which shall be recorded in the special operation contract, shall remain invariable for the duration thereof.’[4]

"In case of modifications to the tax regime, including the creation of new taxes, or the labor participation, or its interpretation, that have consequences on the economics of this Contract, a corresponding factor will be included in the production share percentages to absorb the increase or decrease in the tax burden or in the labor participation of the previously indicated contractor. This correction factor will be calculated between the Parties and approved by the Ministry of Energy and Mines." [3]

"Should the income of the state or the Contractor be materially altered as a result of newtax laws, orders or regulations then, in such an event, the Parties shall agree to make the necessary adjustments to the relevant provisions of this Contract, observing the principle that the affected Party shall be restored to substantially the same economic condition as it would have been in hadsuch change in laws or regulations not occurred. The cost of such restoration to the other Party may not exceed the benefit received by such other Party as a result of such change." [5]

"The Host Government shall take all actions available to them to restore the Economic Equilibrium established under this Agreement and any other Project Agreements if and to the extent the Economic Equilibrium is disrupted or negatively affected, directly or indirectly, as a result of any change (whether the change is specific to the Project or of general application) in [name of country] law (including any laws regarding Taxes, health, safety and the environment) occurring after the Effective Date"[6].

“... the State Authorities [i.e. the host government, local authorities and state controlled or owned entities] shall take all actions available to them to restore the Economic Equilibrium established under the Project Agreements if and to the extent that the Economic Equilibrium is disrupted or negatively affected, directly orindirectly, as a result of nay change (whether the change is specific to the project of general application) in [Azerbaijan, Georgian, Turkish] Law (including any Azerbaijan Laws regarding Taxes, health, safety and the environment) occurring after [date of the HGA or its ratification]... The foregoing obligation to take all 
actions available to restore the Economic Equilibrium shall include the obligation to take all appropriate measures to resolve promptly by whatever means may be necessary, including by way of exemption, legislation, decree and/or other authoritative acts, any conflict or anomaly between any Project Agreement and such [Azerbaijan, Georgian, Turkish] Law" [7]

The purity of contract is based upon The Doctrine Of PactaSuntServandawhich in spite of some differences between definitions given by various authorities means that any contract entered into by two consenting parties shall be guided in good faith. The doctrine of pactasuntservanda can also be said to be found in international conventional la, Article 26 of the Vienna Convention on the law of treaties provides as follows:

"Every treaty in force is binding upon parties to it and must be performed in good faith" [8]

In Anzilotti's description, the doctrine of pactasuntservanda is an utmost suggestion of the use of international legal system.

The Doctrine Of Rebus Sic Stantibus doctrine simple means the permanent sovereignty over natural resources. This principle is regarded as an essential principle in modern international law. The issue of sovereignty over natural resources arises in circumstance between host state and international oil companies in the exploration and exploitation of natural resources within the states territory. It is an inherent and inalienable right of the Host State to change law within its territory. This principle is relevant to stabilization and adaptation clauses and has gained significant grounds in today's practice.

The two major doctrines discussed above gives a background for the discussion of the effectiveness and impact of tax stabilization clause in oil and gas agreements. This raises major questions like, 'Do tax stabilization clause restrict the state from enacting legislations?' 'Do they render the terms of the contract unchallengeable?'. This issue has lingered on in both developed and developing oil producing countries. In my humble opinion, the argument can go both ways. However, tax stabilization clauses do not restrict host state from enforcing new legislation because the state is a sovereign entity, nor is the terms of the contract immutable because both parties can anytime within the life of the contract agree to change certain terms of the contract. On the other hand, such clause binds the hands of the host state because even though it is sovereign state, it cannot enact new legislation without taking into account the interest of the foreign investors and also obtaining their consent.

The practice of using stabilization clauses of some kind is widely established across regions of the world. From an investor's perspective Tax Stabilization Clause are a riskmitigation tool drafted to help protect investments from a number of sovereign risks in the context of foreign investments. Utilized correctly, the host state can also benefit from their inclusion.

As an example of tax stabilization clause, Indonesian Production Sharing Contract, Section XV Other Provisions, stated that "It is agreed further in this contract that in the event that a new prevailing Indonesia Income Tax Law comes into effect, or the Indonesia Income Tax Law is changed, and contractor becomes subject to the provisions of such new or changed law, all the percentages appearing in section VI of this contract as applicable to the portions of contractor and GOI's share so affected by such new or changed law shall be revised in order to maintain the same net income after tax for contractor or all participating interest holders in this contract." [9]

\section{CONCLUSION}

Tax stabilization clause has been widely used in numerous oil and gas contracts. Its major objective is simply maintain the status quo of the tax terms of contract thereby restricting the party to the contract from taking selfless decisions to change the laws of the contract without obtaining the consent of the other party.

Considering the sensitive nature of exploitation and exploration of oil and gas fields, such clauses are not only beneficial to the foreign investors but also in the interest of the host state. It is unrealistic to assert that tax stabilization clause can freeze the terms of the contract throughout the life span because most of the contracts now have an adaptation clause inserted to enable the parties renegotiate the terms of the contract in good faith.

However the mutual understanding by both the host state and the foreign investor can enhance a dispute free contractual relationship.

\section{REFERENCES}

[1] W. Peter, "Stabilization Clauses in Arbitration and Renegotiation of International Investment Agreement," 1995.

[2] M. AFM, "Some reflections on stabilization techniques in international petroleum, gas and mineral agreements," Int. Energy Law Tax. Rev., p. 96, 2005.

[3] "Model PSC of October 2002 for the Exploration of Hydrocarbons \& the Exploration of Crude Oil (Ecuador), Barrows."

[4] Decree-Law 1089 of 1975, Art. 12 and 12.1.

[5] "Unpublished Nigerian Agreement dated 1994, cited from the personal copy by $\mathrm{P}$. Cameron in International Energy Investment Law. The Pursuit of Stability (2010), para. 2.40."

[6] Energy Charter Treaty Secretariat's Model Host Government Agreement in Model Intergovernmental and Host Government Agreements for Cross-Border Pipelines, 2nd ed. .

[7] "Baku-Tbilisi-Ceyhan (BTC) pipeline documentation."

[8] "The Vienna Convention on the Law of Treaties,".

[9] "Indonesian Production Sharing Contract, Section XV." 